\title{
Is There One Right Answer to the Question of the Nature of Law?
}

Dan Priel

Osgoode Hall Law School of York University, dpriel@osgoode.yorku.ca

\section{Source Publication:}

Philosophical Foundations of the Nature of Law. Oxford, UK: Oxford University Press, 2013.

Follow this and additional works at: https://digitalcommons.osgoode.yorku.ca/scholarly_works

\section{Recommended Citation}

Priel, Dan. "Is There One Right Answer to the Question of the Nature of Law?." Philosophical Foundations of the Nature of Law. Eds. Wil Waluchow and Stefan Sciaraffa. Oxford, UK: Oxford University Press, 2013. p. 322-350.

This Book Chapter is brought to you for free and open access by the Faculty Scholarship at Osgoode Digital Commons. It has been accepted for inclusion in Articles \& Book Chapters by an authorized administrator of Osgoode Digital Commons. 


\title{
14 \\ Is There One Right Answer to the Question of the Nature of Law?
}

\author{
Dan Priel*
}

Sir James Stephen is not the only writer whose attempts to analyze legal ideas have been confused by striving for a useless quintessence of all systems, instead of an accurate anatomy of one.

(Holmes 1897: 475).

In Europe, charters of liberty have been granted by power. America has set the example... of charters of power granted by liberty.

(James Madison, quoted in Bailyn 1992: 55).

\section{Introduction}

For some time during the late 1970 s and early 1980s Ronald Dworkin's claim that there are uniquely right answers to virtually all legal questions was the subject of heated debate. But as often happens with such debates, it eventually ran out of steam, even though neither side succeeded in convincing the other. It may therefore seem a bit odd to return to this topic now. If I do so, it is because I wish to examine it from an angle that I think it has not yet been looked at, and which I think is relevant to some debates that are very much alive these days. More specifically, I will argue that there is something about the right answer thesis that fits a certain view prevalent in American political culture about politics and (consequently) about the relationship between law and politics, and that this view is quite different from the British mainstream view about law and politics. The more general and more important goal of this chapter is to challenge the underlying idea of the search for the nature of law, at least so long as it is understood as a conceptual inquiry that purports to tell something about law outside the different political and cultural environments in which different legal systems operate. Somewhat surprisingly,

* I thank participants at the Nature of Law Conference at McMaster University for their comments, and especially to my commentator at the conference, Kevin Walton, and to Stefan Sciaraffa, for his detailed written comments. 
many of the very same legal theorists who have argued vigorously against the view that there is a single right answer to legal questions accepted (or actually, assumed) this position at the meta-level inquiry on the nature of law. I think this is assumption is mistaken, and my chapter is an attempt to explain why.

\section{Changing places}

Returning to his native Britain after a year in the United States, Hart recorded his impressions for the BBC. ${ }^{1}$ These were then published in the BBC's magazine The Listener. This brief piece, "A View of America," reflects Hart's astonishment with what he saw there. Coming from a country that was still slowly recovering from two wars that had left it practically bankrupt, Hart was clearly enthralled about the tall buildings, the wide roads, the big cars, and the bountiful universities. But apart from that, the essay also contains some pertinent comments about American politics and how different they were from what he was used to at home. One thing that particularly impressed Hart was

the passion inspiring so many whom you meet for the moral issue. Argument soon breaks through to what is believed, apparently, to be at the root of every problem-a moral problem. And, more widespread than I could have believed, was the conviction that just as there lurks at the bottom of almost every problem a moral question, so there must somewhere be an answer, an answer perhaps for the sage - and he may be in the university - to provide. (Hart 1958: 89)²

This is also a fairly neat summary of Dworkin's right answer thesis. This description would not be so surprising to those who know something about the debates that would come to dominate legal philosophy in the following decades had it not been for the fact that Hart wrote this some five years before Ronald Dworkin published his first article. And yet Hart was not talking here not about American law but on American politics. This, as I will try to show, is not a coincidence.

Unlike Hart, who only made a few visits to the United States, Dworkin lived and taught in Britain for many years. But he always remained, I think, a relative outsider to the legal and political culture in Britain. He has been, for example, a frequent commentator on American constitutional cases in the New York Review of Books, but to the best of my knowledge has never written a similar essay on a British case. $\mathrm{He}$ has seen enough, however, to note the differences in the political cultures of the two countries, writing once that "public debate in the United States is dominated, to a degree British commentators find surprising, by discussion of what rights

1 Though what I write about may be more accurately described as English, throughout the chapter I mostly talk about Britain and British law. Those troubled by this term should read "England" and "English law" instead wherever these terms appear. Though less loaded, "American law" is also not free from difficulties. Again, I stuck with this phrase aware of its imprecision. I believe that in neither case does my choice of word get in the way of my argument.

2 Surprisingly, even though Nicola Lacey discusses this little essay at some length in her biography of Hart (2006: 193-6), she does not mention this remarkable passage. 
people have" (Dworkin 1985: 31-2). Dworkin's most detailed discussion of British law and politics is found in a relatively unknown pamphlet (or is it a book?) entitled A Bill of Rights for Britain. Summarized in a sentence, in this essay Dworkin recommends that Britain's law and politics be turned into something more or less like their American counterparts. He writes there that in order for people to "participate in government... constantly through informed and free debate... Parliament must be constrained in certain ways in order that democracy be genuine rather than a sham" (Dworkin 1990: 33, emphasis in original). ${ }^{3}$ Such a change, he suggested, might make "[l]aw and lawyers... begin to play a different, more valuable role in [British] society than they now even aim to have." It would encourage courts to "think more in terms of principle and less in terms of narrow precedent." Such a change would help foster "a legal profession that could be the conscience, not just the servant, of government and industry" (Dworkin 1990: 23). In short, Dworkin recognized that there are fundamental differences in the political culture of Britain and the United States, and that those had fundamental implications for the way lawyers perceived their role in society.

\section{Two ways to the rule of law}

I want to suggest that these reflections on the political differences between the United States and Britain that both Hart and Dworkin noticed are relevant to legal philosophy. At this stage I will phrase my argument as weakly as I can: since law interacts with politics, the fact that different political communities have different conceptions of politics is likely to have an impact on their conception of law as well. I will examine this argument in the context of one aspect of the rule of law, namely that of the requirement that the content of the law not be affected by the identity of the person charged with expressing it. This sense is sometimes captured by the slogan "the rule of law and not of men," and is associated with one sense of objectivity, that of non-perspectival constancy or invariance. Put in everyday terms, it is the demand that if different people are asked to state what the law says on a particular question, they will (typically) offer the same answer, even if their political views are different. (This, of course, is not the only sense of the rule of law.)

When legal philosophers address the question they usually do so by trying to connect debates about objectivity in law to the subtle and sophisticated discussions of objectivity among philosophers where the topic has been front and center of virtually every field of philosophy. These jurisprudential contributions provided important correctives to those who rejected the possibility of objective knowledge as naive or even reactionary. However, in focusing on the question of objectivity in these senses they shifted attention away from the issues that lawyers are mostly interested in. For lawyers do not usually wonder about whether Truth exists, or the ontological building blocks of Reality, but they are intensely interested, practically 
interested, in potential problems that could undermine objectivity in the sense I associated with the rule of law. The worry is that people's personal (possibly unconscious) prejudices, their political opinions, or cultural background, will affect their determination of the law thereby undermining the possibility of invariance among different people.

The unique problem of objectivity in law can thus be summarized as follows: (1) law should be (in the specific sense explained above) objective; (2) law (in modern society) primarily is concerned, directly or indirectly, with the relationship between individual and the state; (3) questions of this sort are often politically controversial; (4) legal provisions are often written in vague language that can be interpreted in different ways, and therefore (5) law's objectivity is in danger. More informally, the worry is that, especially in the modern welfare state, there is tension between the aims for objectivity in the law and many of the issues it is made to handle.

Setting up the problem at this level of abstraction is fairly easy. What makes finding a solution to it difficult is that the issue is not simply one of finding the optimal design of legal institutions to minimize a clearly set problem. Part of the difficulty arises from the fact that the understanding of the problem itself changes in different political environments, and therefore that there are several possible ways of understanding what would count as a successful solution to it. One way of understanding my argument below is that we can identify a difference in the mainstream legal academic positions in Britain and the United States not simply about the means of achieving an agreed optimal level of separation between law and politics, but on what kind of relationship between law and politics is desirable. To complete my argument about the error in the way debates about the nature of law are currently conducted I will need to show, first, that the relationship between law and politics is relevant to debates about the nature of law; and second, that different answers to this matter-and as a result different understandings of the nature of law-are going to be given in different political cultures.

My argument below can be summarized as follows. I will first argue that the British response to the problem identified above is to try and keep law away from political questions, whereas the American response has seen various attempts for allowing courts to address political questions without entering the political fray. I will then argue that we can see exactly these different responses in the respective works of Hart and Dworkin. The third step is to show that these competing views mark competing understandings of what law is, which at least in part are the result of competing understandings of politics.

\subsection{The British response}

The traditional, and still typical, response in Britain to the potential challenge that politics poses to the rule of law is to insist on a categorical separation of law and politics. "To call a court 'political' is merely to deny it the character of a court of law" (Oakeshott 1975: 412). This distinction is maintained through the more or less conscious adoption of various institutional mechanisms aimed at minimizing the potential infiltration of politics into the law, and no less importantly, of law into 
politics. Some of these means for achieving that goal are rather familiar, others perhaps less so. I mention only a few of them here:

(1) Parliamentary supremacy. In the course of a discussion of the differences between the United States and Britain Hart wrote how the "defenders of the British government's policy had come to think not merely that Parliament had unlimited legislative powers as a matter of English constitutional law but that it was a general[,] necessary and indeed self-evident truth that government by law could not be limited by law" (Hart 1976: 551). Hart's point was that though the matter was presented as a conceptual truth it was merely a reflection of a particular political choice, one that could be easily refuted by pointing, as Hart himself did in his critique of Austin, to the United States as a counterexample (Hart 1994: 72-4). ${ }^{4}$ The fact is, however, that though there were some who sought to present the matter in this conceptual fashion, the opposition to legal limitations on Parliamentary power was always thoroughly normative. To its proponents Parliamentary sovereignty was a good idea. ${ }^{5}$ One of the good things about Parliamentary sovereignty was that it created a clearer separation between legal and political matters, and made it less likely that courts would be embroiled in the sort of political questions that could compromise their objectivity. This remains a fundamental pillar of British law.

(2) Judicial deference to government action. Another doctrine used to keep law and politics apart has been a very deferential approach to executive action. The general attitude of British courts towards a judicial mindset has been described by a prominent legal historian as one of "total deference to the executive" (Stevens 1978: $320){ }^{6}$ A broad doctrine of justiciability, an almost uninterrupted discretion to public authorities (under what British public lawyers call "Wednesbury unreasonableness"), ${ }^{7}$ and narrow scope for tort liability of public authorities, have all served to keep executive action relatively free from legal oversight. Of course, one can find examples of all that in other places as well, but in comparison to courts in other Western democracies, and more specifically in comparison with American courts, in much of the twentieth century British courts were remarkably timid (Stevens 2005: 31-46). British courts did not, until the last few years, develop a detailed protected rights jurisprudence that set limits to legislative and executive action, as these were deemed inimical to Parliamentary sovereignty.

(3) A non-political process of judicial appointments. Judicial appointments in the UK are made on the basis with relatively little influence by politicians, and are based on an assessment of the legal ability of the candidates. This, of course, contrasts sharply with the fashion in which judges in the US are typically

${ }^{4}$ Many others have made this point against Austin before Hart, e.g. Bryce (1901: 89-94); Sidgwick (1897: 25-8).

5 A summary of the overwhelmingly political arguments against such limitations is found in Goldsworthy (2001: 233-4).

6 Also Stevens (1978: 388-9): "parliamentary sovereignty implied that there should be no serious judicial questioning not only of acts of Parliament, but of decisions of the Civil Service."

7 So called after Associated Provincial Picture Houses v. Wednesbury Corporation, [1947] 1 KB 223 (CA). 
appointed, either in popular elections (in most states) or by a highly politicized nomination process (in the federal courts).

(4) Focus on doctrine in legal education and legal scholarship. What does it mean to be a good lawyer? In the best British law schools this still means, to a degree that would astound American law professors, mastering a vast amount of legal rules by reading a breathtaking number of cases, while giving relatively little consideration to questions of social policy. In a kind of feedback loop mechanism doctrinal legal education is both a product of and a mechanism for maintaining the separation of law from politics: today's students are lawyers and judges of the next generation, and they continue to litigate, interpret, and develop the law in the same fashion. This is not merely a matter of legal education: doctrinal, "black-letter" scholarship-ranging from the brief case note to the comprehensive treatise-is a genre still accorded great respect among British academics. One of the marks of this kind of scholarship is the view that the solution of legal problems is still primarily to be derived from legal materials. As a result even what counts as "theoretical" work in Britain is geared much more towards conceptual analysis or the internal taxonomy of legal categories than to the examination of the law from an interdisciplinary perspective and it often lacks the explicitly normative orientation which is more common in American legal scholarship. This kind of scholarship fosters the view that law and politics are separate domains: social scientific data or political theory belong to politics, "internal" answers derived from the analysis of legal materials are the domain of lawyers.

\subsection{The American response}

The American scene is different. It was already in the first half of the nineteenth century that Tocqueville famously wrote " $[t]$ here is hardly a political question in the United States which does not sooner or later turn into a judicial one" (Tocqueville 2003: 315 [\$I.2.8]). ${ }^{8}$ And this enchantment with law as a central location for political battle has greatly intensified since.

One source of all these differences is the United States Constitution, understood primarily as a legal document that empowers courts to declare certain legislation unconstitutional and that has no equivalent in Britain. Another difference was pointed out by Hart in the very same essay from which I quoted above:

For [the English], surely, liberty is this: that there is a circle round each man, inside which he can do as he please, and it is no concern of others; this is the liberty the Englishman has inside his house and garden and behind its hedges. I think that this as an ideal makes little appeal to an enormous number of Americans; I believe you can find what the American means by liberty by looking at the Constitution of an American State. In the State of Massachusetts the Constitution provides that any member of the public may introduce a

8 It is true that some have questioned Tocqueville's claim (Graber 2004; cf. Schauer 2005), but though it is true that not all political questions become judicial questions in the United States, it is true that American courts have been involved in many politically contested questions, especially in comparison to British courts. 
measure into the Legislature and argue for it before committees. And it seems to me that this is what an American means by liberty; the right to take part in what he would call "the decision-making process". (Hart 1958: 89) ${ }^{9}$

Simply put, politics is a more participatory affair in the US than in Britain, and going to court is one way of participating in politics in the United States. To be sure, there have been many critics, both popular and academic, of the excessive legalism in American life, complaining about too many laws, too many lawyers, and too much faith in the redeeming powers of law. But these persistent complaints need to be repeatedly made exactly because of the staying centrality of law in American political life. They need to be mentioned against a background of statements such as "[l]itigation is an important political activity: courts exercise political authority, modify substantive laws, and allocate resources.... Litigation declares and changes fundamental cultural values" (Abel 1987: 454-5). ${ }^{10}$ (It is hard to imagine such a statement being made in the British context.)

The result of all this is a very different understanding of the relationship between law and politics in American law from the way this relationship is understood in Britain. This makes the fears of law becoming indistinguishable from politics more pressing; at the same time it implies that many of the institutional solutions for maintaining the rule of law that were adopted in British law are simply not available in the United States, and it requires the adoption of different institutional solutions to match the very different problems that arise when courts actively engage in politics. Once again I can only mention briefly a few of them.

(1) Giving up. Perhaps the most radical response to the difficulty is to give up on the attempt to maintain the separation between law and politics. The nomination proceedings of Supreme Court justices are now televised and nominees are assessed in quite openly political terms. In many states judges are elected and can be removed from office by the public. There is a thriving industry of scholarship produced by political scientists assessing court decisions in terms of their political orientation, and in response to the challenge that the law is political some scholars have even openly celebrated the contribution "political courts" make to the American polity (e.g. Peretti 1999). The situation in Britain could hardly be more different. As one of the few political scientists to take an interest in the workings of the courts put it, "[i]t is possible for students of British government to pursue their studies in blissful ignorance of the contents of even the existence of the law reports" (Drewry 1985: 373; Drewry 2009). Compared with literally hundreds

9 Once again Hart captured here Dworkin's view years before he himself articulated it. Dworkin (2011: 365) contrasts one view of liberty according to which liberty consists in the idea that "people must be permitted to play a role in their own coercive government: that government must in some sense or another be self-government" with another according to which "people must be free of coercive government over some substantial range of their decisions and activities." Dworkin, of course, defends the former.

${ }^{10}$ Or consider the following words from Bogus (2001: 41): "American common law is both more democratic and more dynamic than its British counterpart. The people play a larger role in American than in British common law, and the common law plays a larger role in the American than in the British system of governance." 
of books and articles by political scientists examining the extent to which courts are influenced by politics, there is an astounding dearth of studies of this sort in Britain. This lack of scholarly interest can only be explained by the assumption that law and politics are largely separate.

(2) Theories of interpretation. It is not often noted, but there is no British equivalent to American lawyers' obsession with theories of interpretation. This work, at both the statutory and constitutional level, is, at bottom, an effort to find a way to be able to identify the content of law in a way that both acknowledges the political content of the law, but tries to keep law apart from it. This is evident in approaches such as originalism and textualism, which are presented as the only antidotes to the dangers of politicization of the law. But the same is true of other approaches too. Dworkin, for example (whose approach I discuss below), addresses this difficulty by acknowledging the political character of the law, but argues that the right interpretive methodology can avoid the dangers associated with political courts. These debates are required because of, and can be understood as institutional solutions to, the role of American courts in politics.

(3) Economic analysis of law (and "theoretical" scholarship more generally). Economic analysis of law has proven a remarkable success in the United States, but it has not had much impact in Britain. It is tempting to explain this disparity by appeal to the American obsession with theory and contrast it with English anti-intellectualism, but there is, I think, a deeper reason for this difference. In the British context economic analysis is perceived as an alien influence that could potentially lead to undermining the integrity of the law (its "self-understanding"). It is thus not merely pointless, it is potentially dangerous. I suspect that the success of economic analysis of law has much to do with the need to maintain objectivity in the face of law deeply infused with politics. Since doctrinal analysis is no longer perceived as sufficiently robust to prevent the politicization of the courts-this is the realist legacy that has never had much impact in Britain - economic analysis is (or was) conceived as a non-political alternative. At least in its initial stages, it was promoted for its ability to provide precision and objectivity that traditional methods of legal reasoning lacked.

I could list many other ways in which the fundamental differences in understanding the relationship between law and politics manifest themselves in these two legal systems. Political activism in the United States is quite often legal activism; there is much less of that in Britain. (Of course, this may only reflect political activists' prediction that such a course of action would be a waste of time and money; but that is exactly the point.) In addition one may mention the attitude towards judicial review, the different attitude towards deciding politically controversial matters (abortion, slavery, health care), and consequently, the very different place of law in public discourse (US Supreme Court decisions are commonly front page news, but those of its British counterpart much more rarely). If I were to summarize the difference between the two positions in a sentence I would put it this way: the study of the American Constitution is, by and large, a study of American constitutional 
law; the study of the British constitution is, to a much greater degree, the study of British politics.

No doubt the sketch I offered above is very schematic, and on each side there is now growing appreciation of the virtues of the opposing view. In Britain even before the adoption of the Human Rights Act there were those who sought to find a basis for judicial review of legislation in the principles of the common law. In the United States, after years in which judicial review was perceived as the greatest gift American politics has bestowed on the world, there are now those who argue that the US will be better off without it. But in both cases these are still minority views and they are battling very entrenched ideas. It is also possible that British law may be criticized by showing that all the institutional mechanisms mentioned above that are aimed to keep law outside politics fail to do so, and that in fact British law is no less political than American law. And yet at least at the level that legal philosophers seem to be interested in, that of officials' attitudes from the internal point of view, the "self-understanding" of British law(yers) is fundamentally different from that of American law(yers).

\section{Back to the jurisprudential fray}

I suspect the response of many legal philosophers to what I have said so far will be that it is all very interesting, perhaps even true, but that this is not jurisprudence, and has little to do with its concerns. For the general view among them is that "in spite of many variations in different cultures and in different times, [law] has taken the same general form and structure" (Hart 1994: 240). Most legal philosophers accept this statement without argument and have consequently left all the matters I discussed in the last section to others: this is history, or politics, or perhaps constitutional theory or comparative law; this is not jurisprudence properly so called.

What I will try to show is that these matters are relevant to jurisprudence, and indeed have in fact been at the background of some well-known jurisprudential debates. I begin by examining the respective views of Hart and Dworkin and show that they reflect very different views on the relationship between law and politics, and ones that are in accordance with the dominant view on the matter in Britain and the United States, respectively.

\subsection{The different ways of understanding the connection between law and politics}

I began by distinguishing between Hart and Dworkin's perceptions of the other's native country and I suggested that their respective theories of law may have been influenced by their perception of the law in their own native country. This suggestion is not usually well received among legal philosophers. Michael Moore, for instance, considered it the sort of mistake one occasionally hears from students 
who are just embarking on their jurisprudential studies (Moore 2000: 80-1; for a similar attitude see Endicott 1998). Nonetheless, I will try to demonstrate that there may be deep and important truth in this view.

As the quotes above demonstrate, Hart has clearly recognized the differences between American and British political cultures, and has also recognized the very different role of politics in American and British law. None of this, apparently, made him question the existence of a single nature to law. His brief references on the interaction between law and politics, made in the context of discussing American law (Hart 1983: 124-5) did not suggest to him that they had anything to do with what law is. And yet, aspects of his general account reflect the British approach to this relationship which he imperceptibly generalized to claims about the nature of law in general. One place where this is particularly evident is Hart's discussion of adjudication. It is, as he later admitted (Hart 1994: 259) a fairly cursory discussion (which is in itself revealing and unlikely to happen to an American only a few years after Brown v. Board of Education). What is found there is striking, for when Hart has to explain the sources of indeterminacy in the law, he focuses almost exclusively on the inherent vagueness of natural language (Hart 1994: 127-9): It is clear that a car is a kind of vehicle, but it is less clear whether a bicycle is. In other words, the main source of disagreement is not political divergence at the foundation of the legal system (or in his terminology, different people having different rules of recognition due to their different political backgrounds), but rather a local, linguistic disagreement at the periphery of law. It is only when law runs out and the judge is required to fill a void when there is no more law to follow that she will have to consult her moral and political views.

Thus, the British approach to the problem of objectivity mentioned above-that of keeping law and politics separate-becomes a central tenet in Hart's account of the nature of law. Matters are very different with Dworkin. For him the constant contact between law and politics is perhaps the central background problem that calls for solution, the major threat to the possibility of objective law. It is for this reason that he begins his critique of Hart by pointing out that when disagreements occur in the law their source is usually political, not linguistic. Dworkin therefore starts his analysis at a point that those who wish to maintain the separation of law from politics would already find unacceptable: "Judicial decisions," he says, "are political decisions" (Dworkin 1978: 88). Thus, the separation between law and politics, in the way it is understood in British law-two (largely) non-overlapping domains - is off the table from the start. Instead, Dworkin seeks to solve the problem of objectivity by relying on a distinction between what I will designate as "politics" and "Politics." (The terms are mine.) The former is what one sees on TV: spin, personal attacks, simplistic slogans, talking points instead of argument; it is also the kind of things that give politics a bad name: logrolling, filibustering, the adoption of unprincipled position for the sake of personal promotion. For politics Dworkin has nothing but contempt. Debates preceding "legislative decision[s] about some great issue of principle" are "rarely" of "high quality." Rather, such "[o]rdinary politics generally aims ... at a political compromise that gives all power- 
ful groups enough of what they want to prevent their disaffection, and reasoned argument elaborating moral principles is rarely part of or even congenial to such compromises" (Dworkin 1996: 344-5; also Dworkin 1985: 146). By contrast, Politics is commitment to principle through the exploration of the moral requirements involved in living in a community. He says, for instance, that in a community governed by "the model of principle" members of the community "accept that they are governed by common principles, not just by rules hammered out in political compromise." And he adds: "Politics has a different character for such people. It is a theater of debate about which principles the community should adopt as a system..." (Dworkin 1986: 211). ${ }^{11}$

What is the role of law in this? Dworkin's answer is that law, properly understood and practiced, is true Politics. The first step in the argument is that "our government shall be republican rather than despotic" (Dworkin 1996: 111, also 345 , for a similar emphasis on a "republican" view of law), and the recognition that what I called "politics" "destroys civic republicanism" (Dworkin 2000: 234, also 369, where Dworkin links the "degraded and negative" political discourse in the US to the claim that Americans cannot claim "with a straight face, to be governing [them] selves"). The second step is that law is the main means for promoting this republican ideal:

We have an institution that calls some issues from the battleground of power politics to the forum of principle. It holds out the promise that the deepest, most fundamental conflicts between individuals and society will once, someplace, finally, become questions of justice. I do not call that religion or prophecy. I call it law. (Dworkin 1985: 71) ${ }^{12}$

Law and lawyers thus have a dual role within the American polity: one is to elevate politics to Politics by providing a model of what political discourse should look like; the other is to limit the domain of politics by transferring certain questions from politics to law (and thus to Politics) if politics cannot be transformed into Politics. The first strategy is in view in Law's Empire when Dworkin argues that political decision making should be based on the same principles and reasoning that guide legal decision making (Dworkin 1986: 184-6; Dworkin 2006). ${ }^{13}$ Elsewhere Dworkin explains that political institutions could rise to the level of Politics only under what he calls "partnership democracy," which, as its name indicates, is distinctive for its participatory view of democracy-one that works to encourage the kind of political debate he sees in judicial proceedings.

However, when the political community fails to create this form of democracy Dworkin is clear in favoring the second strategy: "individual citizens can ... exercise

\footnotetext{
11 For comparison consider Crick (2000: 32), a book that has a good claim to be the classic view of politics in Britain: "'Politics'... simply summarizes an activity whose history is a mixture of accident and deliberate achievement....It is not as such motivated by principle.... Political principles are, whatever they are, principles held within politics." See also Crick (2000: 47).

12 Dworkin (1996: 345) offers a (highly romantic) explanation of how law achieves this. Friedman (2004: 1290-1) makes precisely the same point.

13 I criticize the position of Dworkin (2006) in Priel (2007a).
} 
the moral responsibilities of citizenship better when final decisions involving constitutional values are removed from ordinary politics and assigned to courts, whose decisions are meant to turn on principle, not on the weight of numbers or the balance of political influence" (Dworkin 1996: 344; also' Dworkin 1978: 85). The judge's role in this debate is not that of a follower (of rules set elsewhere), but primarily as that of a moral leader. For this reason we even find in Dworkin, an exhortation for (as Hart put it) "the sage... [who] may be in the university" to provide the right answer to political questions. ${ }^{14}$

Accepting that, the question still remains how we can know-even in a partnership democracy-that such debates would give us the objectively right answer to the questions of Politics. The answer, quite simply, is that the right answer is the best answer to come out of the debate. This crucial point about Dworkin's position is central to his thinking: the right answer is not "out there," it is simply what emerges as the "winner" in a principled debate. It is always a tentative winner, because it is always open to challenge, but an objectively right answer means, for him, nothing more than the best answer so far found, the one that we have been convinced cannot be successfully challenged, in proper political (i.e. Political) discourse.

What is often missed in jurisprudential discussions of Dworkin's work is the extent to which his account reflects a view that is fairly familiar within American legal discourse. To see this we must step outside the narrow bounds of analytic jurisprudence, although because of space limits I can provide here only one detailed example. ${ }^{15}$ In an essay first published in 1981 (now reprinted in Fiss 2001) Owen Fiss has sought to address the challenge to objectivity posed by certain thenemerging critical scholars. Proponents of this "new nihilism" contended, as Fiss put it, that "[a]ll law is masked power" (Fiss 2001: 151). Fiss's response was somewhat different from Dworkin's: unlike the latter who denied the intelligibility of external criticism Fiss acknowledged it and even relied on it to distinguish between internal legal criticism and external ethical (or religious) criticism. But what looks at first like a significant difference turns out to be quite small, for as Fiss put it, "[e]ndogenous change is always preferred... [and therefore t] he external critic struggles to work within the law..." (Fiss 2001: 159; also 160-2, for an elaboration on the ways in which appeal to morality is required to maintain the objectivity of law).

One need not accept Fiss's romanticized view of American law to recognize in his words a particular vision of addressing the challenge to the objectivity of law, one

14 Recall: "The courts are the capitals of law's empire, and judges are its princes, but not its seers and prophets. It falls to philosophers, if they are willing, to work out law's ambitions for itself, the purer form of law within and beyond the law we have" (Dworkin 1986: 407). To the same effect, Dworkin (2011: 109).

15 Another famous example that is superficially very different but bears some deep unmistakable resemblance to Dworkin's ideas is Wechsler (1958), contrasting "the ad hoc in politics" with the "judicial process...that ... must be genuinely principled" (1958: 15), and who, interestingly, contrasted his approach to that taken by the House of Lords (1958: 17). There are also looser links between Dworkin's idea and much other work that has sought to reconcile the republican ideal of self-government of "We the people" of the Constitution with the higher law, the "unalienable Rights," mentioned in the Declaration of Independence, and the role of law in answering this question. 
that seeks to find it through engagement in moral and political debate within an "interpretive community" (Fiss 2001: 170). The judges' authority derives from the fact that they "are insulated from the political process" (i.e. what I called politics), but that is so in order for them "to engage in a special kind of dialogue over the meaning of [public] values" (i.e. what I called Politics). This judicial engagement with public values is "an essential part of the process through which a morality evolves and retains its public character" (Fiss 2001: 199). For this reason "courts should not be viewed in isolation but as a coordinate source of governmental power, and as an integral part of the larger political system" (Fiss 2001: 54, also 34-5). ${ }^{16}$

The view reflected here, then, is not simply that morality contains right answers to moral questions, and since morality is part of the law, law contains right answers too. (Note also that it has nothing to do with whether morality is a condition of validity.) At bottom Dworkin's view holds that law can transform political debate and in this way avoid the problem of objectivity: following his prescription is what it means to find the right answer to moral questions. If one accepts this view the audacious right answer thesis becomes trivial, you might even say tautological. But in the Hartian perspective it is almost incomprehensible. Because Hart does not recognize the distinction between two kinds of politics, on his view when politics is introduced into the law, political disagreement is simply "reproduced" in the law. It is hard to see how that could aid the search for legally correct right answers or guarantee the objectivity of law. This view is evident when Hart criticizes those who think that "there is no central element of actual law to be seen in the core of central meaning which rules have, that there is nothing in the nature of a legal rule inconsistent with all questions being open to reconsideration in the light of social policy" (1983: 72, emphasis in original; Shapiro 2011:327-9, argues against Dworkin on the basis of a similar attitude). For Hart to recognize the existence of law is to recognize a domain in which politics, even Politics ("social policy"), cannot touch. ${ }^{17}$

\subsection{Legal validity?}

What we have seen so far is that the relative separation of law and politics in English law replicates itself in Hart's account of the nature of law, whereas the deep ties between law and politics in American law are at the heart of Dworkin's theory of law. That this fact has not received much attention is not, I think, a coincidence. Unlike the connections between law and morality, the interaction between law and

16 Another similar suggestion is found in Barber and Fleming (2007: 156): the right approach to constitutional interpretation, they say, "can only mean an interpretation of the Constitution that tries to redeem its expressed claim to be an instrument of justice, the general welfare, and the other goods listed in the Preamble." Such examples could be easily multiplied.

17 The two jurisprudential views thus reflect two opposed views on the place of law in practical reasoning. Hart's positivism sees law as concerned with guidance, and clear guidance requires replacing moral reasons. Dworkin's view sees law as concerned with participation and ultimately in selfgovernment, and hence sees the point of law in engaging people in moral reasons. The issue is explored more fully in Priel (2012b). 
politics has been marginalized in analytic jurisprudence. Perhaps this reflects the dominant view that morality is constant and therefore the relationship between it and law is (fairly) constant too. (This is true also of moral anti-realist legal philosophers such as Kelsen or Alf Ross. ${ }^{18}$ ) As such the law/morality borderline seems to match an inquiry into the nature of law (as currently understood) much more than the shifting boundary between law and politics. But in ignoring the law/ politics divide legal philosophers may have missed the most important challenge to their search for a single nature to law. The purpose of this section is to show in what way the differences identified above between British and American law about the place of politics, and the corresponding differences between Hart and Dworkin, reflect a difference that does not merely reflect different variations on a single nature of law, but must be understood as competing answers to the question "What is law?"

To the extent that the question of the relationship between law and politics is addressed in jurisprudential literature it is typically located in the rule of recognition. According to a popular view (found already in Hart 1994: 71, 106, 247) whereas the Americans have adopted a constrained sovereign, the British have not. Translated to the language of contemporary jurisprudence this means that moral considerations make up part of the American rule of recognition but not part of the British one.

There are various problems with this claim, not least that it assumes that what is at stake between competing jurisprudential theories are different perceptions of legal validity. ${ }^{19}$ In the present context, this view fails to capture the sense in which the British constitution is fundamentally a political, not a legal, entity (it is difficult to talk about a "document" in this context). It is a constitutional structure in which "[e]verything that happens is constitutional. And if nothing happened that would be constitutional also" (Griffith 1979: 19). ${ }^{20}$ It is from this that law is understood as simply the voice (the "command," if you don't mind the Austinism) of whoever happens to be in power. Sovereignty on this view is the power to make laws. It is a power that the otherwise unlimited sovereign can choose to create legal limits on its law-making power. This is, effectively, the way Hart interprets the US Constitution (Hart 1994: 68-9), and this is how today the Human Rights Act is reconciled with the doctrine of Parliamentary sovereignty. By contrast, in the United States sovereignty is ultimately understood to vest in the people (Wood 2002: 159-62), and the Constitution, created by the people, is thought to award some limited powers, including limited law-making powers, to the different branches of government. As such the law is understood fundamentally not as the manifestation of political authority, but as what sets its limits (cf. Bailyn 1992: 175-81, 185-8, 201-3). In the British picture judicial engagement in politics is ultimately an

18 Though popular (especially among philosophers), the view that morality is largely unchanging is not universally accepted. My view is that Dworkin, despite his endorsement of moral objectivity, rejects this position. This by itself is a significant aspect of his work, that is very relevant to understanding his jurisprudence, but not one I can consider here.

19 I challenge this view in Priel (2011a).

20 Griffith's terms are stark, but the idea is an old one. Bagehot expressed a similar idea when he said (1963: 221) that "The ultimate authority in the English Constitution is a newly-elected House of Commons." On the decline of the idea of fundamental law in Britain see Gough (1961: 168-207). 
illegitimate attempt to usurp political power, to undermine the sovereign; in the American one, judicial engagement in politics is an (almost) inevitable outcome of the need to make sure government does not exceed its given powers.

This is the philosophical divide that makes intelligible so many of the differences between law and politics between the two countries. These two views emanate from two very different underlying political theories about what makes the use of political power legitimate, and they shape the most basic features of what law is in these two countries. Yet in the present picture all this is treated as irrelevant to understanding the nature of law, quite possibly exactly because these differences are the result of competing political theories. But once we see this, much of what I said above that was inexplicable in the "validity-first" picture that is dominant in contemporary jurisprudence begins to make sense. It is not simply that the United States and Britain have different tests of validity. It is that they have different political traditions, which result in a different understanding of what law is, which in turn explains numerous practical differences between their legal systems.

\section{The implications for the search for the nature of law}

John Gardner once described Dworkin's work as that of a "theoretically ambitious lawyer" (Gardner 2004: 173), suggesting that for all that is valuable or interesting in it, it is not really legal philosophy. I suspect my argument would be classified in the same way: indeed, exactly because my discussion reveals such differences between American and British law it might be judged irrelevant to the question of the nature of law. I suspect what I have said so far might be similarly dismissed as insufficiently philosophical. There were just too many facts, too much history, perhaps even too much law, to count as proper legal philosophy. These are exactly the kind of contingent matters that legal philosophers consider to be the domain of others. Rather than a reason for criticizing legal philosophers, one might say my discussion so far shows that they have been correct to ignore all these matters.

In proper philosophical style, then, let me present a syllogism:

(1) There is no right answer to what constitutes "true" politics, or no single account of the legitimacy of the state; there is, if you wish, no non-political "nature" to politics to be discovered through conceptual analysis.

(2) Different states have different forms ("conceptions") of politics that reflect their different values, traditions, and history.

(3) There are connections between law and politics.

(4) Different understandings of politics result in different roles, understandings, forms ("conceptions") of law in different states.

(5) The different conceptions of law go to the heart of what on any plausible view of the matter counts as the nature of law.

Hence: (6) The search for the (single, unique) nature of law is misguided. 
I did not argue for (1), but I assume (and hope) it would not be controversial. Denying it is hardly going to help the search for the nature of law, for that would only mean that for the sake of an account of the latter, legal philosophers (unless they deny (3)) would have to develop a side-specialty of identifying the true nature of politics. In any case, my demonstration of (2) above can be seen as validation of (1) as well. (3) too is, I think, uncontroversial. It is the remaining premises, (4) and especially (5), that are likely to evoke most resistance, but my argument in the last section has shown, I hope, the very different understanding of politics in the two countries, and how they result in a profoundly different understanding of what law is. To reiterate just one point noticed by Hart, the dominant idea of freedom in Britain saw it as the opposite of law; in the United States, freedom was a product of law. This is a fundamental divide that explains not just the fundamentally different understandings of what counts as law, but also many of the lower-level differences between law in these two countries. The alternative advocated here to the prevailing jurisprudential orthodoxy claims that these facts must figure in any attempt at depicting the "nature" of American and British law. I argue that any inquiry that purports to account for law's "selfunderstanding" but cannot account for these differences, fails in the task it sets for itself.

Those who wish to reject my argument might contend that at best what it shows is the need for making discussions on the nature of law more abstract. Now, of course, one may define the term "nature of law" any way one wishes and it is definitely possible to define it to mean those necessary features we happen to find in all legal systems. Even then I think my argument above shows that one is likely to find much less than most legal philosophers seem to think. More importantly, even if the nature of law simply means those things that are necessarily true of all legal systems, one would then wonder why this question is of any interest: Is philosophy in the business of collecting necessary truths about things in the world? The search for the nature of law was presumably considered worth engaging in because it was believed that by engaging in it one could learn something valuable about a certain social practice; it was believed that the search for the nature of law was somehow illuminating of the law. The solution suggested here avoids the challenge posed by giving the term "nature of law" a purely technical meaning and by stripping this kind of inquiry of value. This solution to my challenge, then, looks more like an admission of defeat.

If the search for the nature of law is to be meaningful, and if it is to bear some resemblance for what most people mean when they talk about the "nature of X" or "essence of X," namely an inquiry that gives us the most significant aspects of a certain phenomenon, such an inquiry should be understood in quite different terms. I propose, informally, that a fact belongs to the nature of a thing if it explains many other facts about it. Slightly more formally, a fact $F$ is part of the nature of social practice $S$ if (and only if?) it figures in an explanation of many features of $S$. Even the more formal definition is still imprecise, but for my purposes here it will do. I propose that the way the relationship between American and 
British law and politics is part of each legal system's nature, as defined here, for one thing we have seen above is that the relationship between each legal system and politics was part of the explanation of very many aspects of each; and though I have said nothing about it, they are also relevant for explaining some of the differences between the content of the laws of those legal systems.

All this does not amount to a logical proof, but it does amount to a demonstration that two legal systems have a very different understanding of what law is as a result of their different political traditions and their corresponding differences in understanding the relationship between law and politics. There is, however, a logical challenge I can direct at defenders of the nature of law project: the issues raised in this chapter can be deemed irrelevant only if American law and British law belong to the same kind, otherwise the differences between them are simply irrelevant to the question of each legal system's respective nature. In other words, there is a different way of understanding my argument, i.e. as the claim that American law and British law are different kinds, in which case the set of facts I described about each law may be necessary for understanding its nature but irrelevant to understanding the nature of the other. Put differently, my point is that when proponents of the prevailing understanding of nature of law rely on examples from both British and American law in support of their views on the nature of law, they assume without argument that the two are species of the same kind. However, from a logical point of view there is warrant in doing so and there is no telling whether they are right on this matter. Since there is no fact of the matter on this question, the assumption that they are- an assumption that is crucial for the entire enterprise of the search for the nature of law-is unwarranted. Furthermore, this assumption can only make sense if one implicitly assumes some further substantive views about what law is. The whole enterprise is thus in some sense circular as it can only get off the ground by presupposing the truth of certain premises that are presented at the end of the inquiry as findings about the nature of law. (This problem is complicated many times over when other legal systems, contemporary, historical, some may even want to add hypothetical, are added to the story.)

To amplify this last point imagine you had been asked to offer an account of the nature of American law or the nature of British law, a sort of account of the central features of the legal system, one that includes the self-understanding of lawyers in each of these legal systems as to the enterprise they are engaged in. We could conclude that British and American law belonged to the same kind only at the end of our inquiry if we found out that the accounts of each that we had previously offered turned out to have a roughly identical core and that their differences were only confined to those aspects that we had not considered as part of either legal system's core. But if we attempted to undertake such an inquiry and found out that the accounts were conflicting at their core that would imply that these two legal systems do not belong to the same kind. My claim in this chapter is that when we do just that, it turns out that the two legal systems indeed conflict at their core. Of course, I may be wrong about that, but until something like this is tried-and I know of no legal philosopher writing on the nature of law who tried to do that-the entire project rests on wholly question-begging assumptions. 
Perhaps, however, we may understand the search for the "nature of law" more weakly, i.e. as not actually concerned with finding the nature of law. Instead this term might simply designate an attempt to look at law from some greater distance, without any commitment to classificatory accuracy. Is the difference between my views and those of legal philosophers looking for the nature of law nothing more than that they prefer the long shot view whereas I am more interested in the close up? I do not deny that standing at some "distance" from a phenomenon can reveal what a closer look may miss (Jackson and Pettit 2004). Even understood in this more relaxed way, however, there is a serious problem with it, for if this is the reason for the search for the nature of law, then the right distance from the object of inquiry is not to be determined by the object of inquiry. Rather, it must be chosen by legal philosophers according to criteria that are external to the object of inquiry. As on this view there is no correct degree of "zoom," the only appropriate way of choosing between various possible distances must be determined according to what we gain from the explanation. If that is the case, my view is that in their search for the nature of law legal philosophers have been standing too far from the law, and that some of the debates that preoccupied legal philosophers in the last few years under the banner of the nature of law were deeply unilluminating of their object of inquiry. Don't take my word for it: on this interpretation of the search for the nature of law a good test for the optimal "distance" from an object of inquiry is the degree of interest others find in it. The fact that both legal academics and moral and political philosophers (let alone practitioners or lay people) have not found much of interest in these debates, is more than suggestive of the fact that the distance from the object chosen by legal philosophers has been the wrong one.

Opting for the distant explanation can also lead to the opposite problem, viz. the tendency to assume the local and familiar is general and universal. I have already suggested what may be a problem in the work of both Hart and Dworkin: an assumption that one can extrapolate from the legal system one is familiar with to universal claims about the nature of law. Let me illustrate this point with another example. A few years ago there was an internet debate on the question why AngloAmerican legal scholars take relatively little interest in the work of Hans Kelsen and in deontic logic, both topics on which legal philosophers from continental Europe write much more. The debate attracted many prominent legal philosophers, who offered various explanations. ${ }^{21} \mathrm{I}$ read this exchange and was struck by the fact that, with the exception of one fleeting comment (by an Italian, made with regard to Kelsen), no one mentioned what I thought was the obvious explanation. Kelsen's legal thought, despite his many years in the United States, remained firmly rooted in a particular conception of law that is closer to what one finds in civil law systems. Once it is recognized that for all its abstraction Kelsen's approach fits some legal systems better than others, the puzzle is solved. The same is true of deontic logic. Deontic logic would be considered important for analyzing legal argument in a legal

21 See <http://prawfsblawg.blogs.com/prawfsblawg/2007/10/why-no-deontic-html〉; <http://prawfs blawg.blogs.com/prawfsblawg/2007/10/why-no-kelsen.html>; <http://leiterlegalphilosophy.typepad. $\mathrm{com} /$ leiter/2007/10/why-dont-amer-1.html (all visited, April 8, 2011). 
system that puts a premium on deductive argumentation. This is exactly what one finds. A prominent German legal scholar has recently written that even today " $[t]$ he typical German judgment, like its French counterpart, strives after the ideal of deductive reasoning" (Zimmermann 2005: 27, also 38; similarly Markesinis 1986: 366). By contrast, legal philosophers from common law jurisdictions, told from Day One of law school that "[ $\mathrm{t}] \mathrm{he}$ life of the law has not been logic; it has been experience" (Holmes 1881: 1), ${ }^{22}$ are much less likely to think that deontic logic is going to capture anything important about the law.

I point out these vestigial localisms in supposedly general theories of the nature of law not in order to castigate particular legal theories for their insufficient generality, but to point out that legal philosophers' tendency to stand far away from legal practice, their relative lack of interest in the nitty-gritty details of the organization of particular legal systems, all adopted in the name of the search for the nature of law, may actually result in too quick generalizations from few familiar cases and thus undermine the inquiry for the nature of law.

Perhaps noticing the difficulties with talking about the nature of law in general, several legal philosophers have turned in recent years to talking about "our" concept of law (e.g. Raz 2009: 94-5). Unfortunately, this seemingly more modest claim suffers for the same problem of demarcation: Quite simply, there is no logical way of demarcating "our" concept of law without circularity unless we have a nonquestion-begging way of demarcating who "we" are, and none of those who suggested this possibility has even hinted towards a way of addressing this question. This is not a fanciful complaint. In challenging the search for the nature of law I relied not on anthropological studies of small pre-industrial communities living in the thick of the Amazon rainforests, not on the law of an ancient and now extinct political community, not on the law in contemporary Russia, ${ }^{23}$ not even on the distinction between common law and civil law that some have suggested involved some fundamentally different ways of thinking (Legrand 1997). I looked at the two legal systems from which the most prominent analytic legal philosophers hail, two legal systems that share a long history. If "our" does not include both of them, I do not see what this word is supposed to cover.

At this point the challenger may reply that I am wrong to say that we have no way of knowing that American and British law are not the same kind: after all, people treat them as belonging to the same kind, which is why, for example, they consider it a valuable exercise to compare them. This response, however, is both unconvincing and self-defeating. It is unconvincing, because it is asserted rather than shown. The fact that people use the same word to describe both is not sufficient to tell us that the word is used to refer to the same kind. (We are, after all, repeatedly reminded that legal philosophy is not lexigraphy.) This usage is perfectly acceptable for everyday

22 Several American philosophers (e.g. Dewey 1924; Cohen 1916) have expressed similar views on law. Many other statements expressing the same idea from English and American judges and scholars are found in Waddams (2003: 1-2).

${ }^{23}$ For example Ascherson (2004): "when [Putin] says 'law' he means what we would call 'order'." The issue is discussed further in Kahn (2006) and Kurkchiyan (2003). 
purposes, but it does not require commitment to the view that the things described by the same word share certain necessary features. In fact, my guess is that if you asked some British lawyers what they thought of American law, many of them would reply "it has the appearance of law, but it really is politics masquerading as law," 24 or, more politely, that American law is a very different beast from British law. This answer is also self-defeating because if we take people's attitudes seriously then we should pay at least as much attention to their profound thoughts and self-understanding of their own legal system as to their superficial comparisons with others. Put differently, one cannot invoke people's attitudes at one point and ignore them completely at another. And it has been exactly my claim that those attitudes are profoundly different in Britain and the United States.

\section{Some further objections answered}

I foresee four additional objections to the position taken here. The first is that the argument must be wrong because the existence of a debate on the question of the nature of law shows that there is something that the disputants are talking about. Andrei Marmor (2001: 6) once wrote that "controversy over the content of a rule of recognition does not prove that there is no such a rule. Even when there are several ways of understanding a rule (or anything else for that matter), there must be something there that people can understand differently and argue about." Though the context of this remark was different, Marmor's parenthetical remark shows he considers his point to be general. Transferred to our context the argument would be that the fact that people disagree about the nature of law shows that such a thing exists. Unfortunately, this is a bad argument. Controversy may be the result of shared mistaken belief over the existence of something that in fact does not exist. No one (I hope) would infer the existence of God merely from the existence of debates about the nature of God. In our context, debates about the nature of law could exist so long as participants share the mistaken belief that such a thing exists. The purpose of this chapter is exactly to challenge this belief.

A second objection is the opposite of one of the objections considered above, i.e. that I have been tendentious in my choice of two very different legal systems for discussion. There is American exceptionalism (including American legal exceptionalism) on one side and British exceptionalism (in not having a written constitution) on the other. If I had chosen different countries, I would not have gotten such different outcomes. There are, however, several problems with this objection. One is, of course, that in some respects the American and the British legal systems are fairly close: they are both legal systems of Western developed countries with a long shared history. And as already mentioned, these happen to be the countries from which the most prominent analytic legal philosophers come from, and it is very rare indeed to hear them thinking of either (or both) of these legal systems as somehow

24 I have not conducted a survey but Stevens (2009: 651) and Birks (1996: 98-9) come close to saying just that. 
an outlier in the search for the nature of law (especially when the whole point of the search for the nature of law is to find those features from which there are no outliers). ${ }^{25}$ The most important point, however, is that the moment one starts looking closely, virtually every country is "exceptional" in one way or another. French law and German law are the paradigmatic examples of civil law jurisdictions, and yet there are important fundamental differences between them; German law has served as the model of much Chinese law, but there are fundamental differences between German and Chinese law as well. This does not entail (nor did I argue) that each legal system has its own "nature," or even that nothing illuminating can be said about law in general. It says, however, that in order to identify without circularity what belongs to the object of inquiry one must identify a certain role that law plays within a certain social or political organization. Because of the variety of such organizations, it cannot be assumed in advance that the thing called "law" in all of them will have the same nature. This is only something we could find at the end of our inquiry.

This point leads to the third challenge, and that is that my argument in fact shows that law has a nature, namely that the law is concerned with objectivity. The critic may even go on to quote me saying that there is "tension between the aims for objectivity in the law and its subject-matter." Can I make this statement without assuming law has some nature? This is an important point for clarifying the scope of my argument. First, as already said, I do not deny that there are certain observations true of both American and British law (and quite possibly of other legal systems). There may even be observations true of legal systems more generally. But to observe at legal systems and notice some things they have in common is not philosophy, and it is best done with recognized fact-gathering techniques that, to put it gently, are not the mark of contemporary legal philosophy. Second, there may be some "philosophical" questions (whatever that means exactly) that arise with regard to many, perhaps even all legal systems. But these "puzzles" (as I called them in Priel 2007b: 193-5), need not, singly or together, amount to anything that could plausibly be called the nature of law (unless one uses this term in the purely technical sense mentioned above), nor do these puzzles become less puzzling if they are found to be true of only some legal systems. Most importantly, there is no reason to think in advance that even if the same puzzle arises in all legal systems, that the answer to it will be the same in all legal systems. To pick a favorite puzzle, it is perfectly possible that we will have one explanation for the normativity of law in a contemporary modern welfare-state democracy and quite another one in a medieval feudal society. We have seen a different understanding of the relationship between law and politics between British and American law; the differences may be even greater in a place where an absolute monarch declares "the state is me." Since law is not something that falls on societies from the sky with a note "take me or leave me"

25 Atiyah and Summers (1987: 256, 411-20) is a rare (and perhaps for this reason neglected) exception. 
attached, it can be (and has been) molded according to the particular political culture in which it exists. No one doubts the truth of this claim as far as the content of law is concerned; what I do here is extend it to the deeper and more general elements of different legal systems.

The last objection I can foresee is that what I have argued so far is a kind of a skeptical claim. As such it may be an amusing intellectual game, but like other skeptical claims we should really ignore it and go on with our daily business, including philosophers' daily business, which has always been the identification of the nature of things. However, if my claim is "skeptical" in any sense, it is skeptical only with regard to a particular, and in historical terms recent, understanding of jurisprudence. In the English-speaking world it was not before John Austin that jurisprudence was understood in this way (and I would argue that even he is a questionable case). Before him there is simply no one that I know of, definitely not Bentham or Hobbes, who was concerned with the question of the nature of law in the manner this term is understood these days. It was only around fifty or so years ago that Anglophone legal philosophy turned in earnest to this question (in German-language jurisprudence things may have begun a bit earlier); this happened at a particular point in history, when other branches of Anglophone philosophy were also interested in questions of a similar kind. And yet in other areas these questions were fairly quickly abandoned: already in 1979 Brian Barry, who knew a thing or two about the time and place in which this sort of inquiry flourished, wrote mockingly about questions of this sort, "I cannot remember when I last read a discussion about the criteria for a good cactus or an extra-fancy apple" (Barry 1979: 632). ${ }^{26} \mathrm{It}$ is, I think, no coincidence that the revival in political philosophy, pronounced dead in 1960 s, took place at the time that interest in such "conceptual" questions declined, and by now, in many branches of philosophy the search for the "nature" of things has come under attack and has been largely abandoned. ${ }^{27}$

26 But unlike other areas of philosophy this sort of question seems to be alive and well in jurisprudence (Dickson 2009). It is notable that it is mostly legal positivists who seem concerned with these sorts of questions, whereas natural lawyers like Finnis and Dworkin dismiss them as unimportant. This should have alerted legal positivists to the fact that these natural lawyers are not in the business of giving an analysis of the nature of law, but rather of giving a political (non-neutral) account of law. Many of the apparent tensions Dickson finds in the work of Finnis (Dickson 2009: 170-3), disappear if this is realized. In the case of Dworkin, the matter is discussed in more detail in Priel (2011a).

27 See e.g. in metaphysics: Van Fraassen (2002): chapter 1 entitled "Against Analytic Metaphysics;" in epistemology Stich (1990: 19-21): section entitled "The Irrelevance of Analytic Epistemology;" Kitcher (1992); in ethics Darwall et al, (1992: 123): describing how "[m]oral philosophers shed the obsessions of analytic metaethics;" Timmons (1999: 15-30): describing the move from analytic to post-analytic metaethics); in philosophy of mind Fodor (2004); and generally Harman (1999). They could all be wrong, of course, but to suggest that abandoning the search for the nature of law is somehow anti-philosophical displays lack of awareness on what some of the world's leading philosophers think is (and is not) philosophy. 


\section{From the nature of law to human nature?}

Does this mean that it makes no sense to talk about the "nature" of law? If we mean by this term what most legal philosophers have given it in the last fifty years, then I believe the inevitable answer is "yes." 28 The only way to avoid the problems raised here is to engage in normative inquiry. Whatever its faults may be such an account would not suffer from the problem of circularity identified above. Such an account can be more sociological or historical-seeking to understand the development of law in a certain time or place, to answer what law was for those living then, or it can be more directly normative, seeking to explain where law fits within a political theory, what law must be in order to be legitimate. On certain assumptions the latter account may be universal in the sense that it applies in all places, not in the sense that it exists in all places. (Claiming universality for such an account presupposes that there is one way law may be legitimate, and this assumption may be false.)

Perhaps, however, there is a completely different way of thinking about the way to get to a universal account of the nature of law. Perhaps the nature of law is not a matter to be discovered by a priori reflection on law, but rather by looking more at bumans and their nature. This idea may sound new, but it is in fact one as ancient as jurisprudence, and it is only the lack of interest of most legal philosophers in the history of their subject (prior to 1961) that may have obscured this point. It is part and parcel of the natural law tradition, and it is also central to the work of those often considered the first legal positivists, Thomas Hobbes and Jeremy Bentham. Since this organizing idea has been rejected, probably with the work of John Austin, jurisprudence has been losing its way (Priel unpublished). ${ }^{29}$

A contributing factor for the lack of interest in human nature may have been the skepticism towards the idea in the humanities and social sciences around the time Hart published The Concept of Law. More recently, however, the idea of human nature has undergone something of a revival. Building on work in psychology and anthropology that identified numerous traits and habits found in all human societies (Pinker 2002: 435--9, passim), there have been some attempts to extend these ideas to law (Kar 2006; Guttentag 2009; Mikhail 2011). Without passing judgments on any of the particular ideas defended in these works, I will say that I am sympathetic to the view that scientific findings could contribute to questions that have traditionally been thought to belong to philosophy (Priel 2011b; Priel

28 For the sake of completeness I should add that my argument here is not the only one I have advanced against this sort of inquiry. Others appear in Priel (2007b, 2008). Against the "case study" approach of the present chapter, the approach taken in these two essays in more abstract.

29 In Hart (1994: 193-200) we still see the remains of this approach in the brief discussion of the minimum content of natural law. It contains some, broadly Humean, remarks about human nature, but even these are mostly negative (i.e. an attempt to challenge what he considered to be mistaken views about human nature espoused by natural law theorists) and their relevance for understanding the content laws are likely to have, but not the basis for Hart's positive account of law. Even this minimal concern for human nature is gone in more recent work by legal positivists, who have told us that an account of the nature of law must be able to explain what law is even for non-human societics. 
2012a). It is worth bearing in mind, however, that at this stage the research this work is based on is still controversial, and its relevance to jurisprudence raises additional difficulties. I cannot discuss these issues here, but I wish to highlight two points about how different this approach would be from the currently dominant view in jurisprudence. First, these inquiries rely heavily on factual discoveries of social and cognitive scientists, whose methods are very different from those used by contemporary legal philosophers. Second, the substantive results of this approach are also likely to look quite different from those of contemporary jurisprudence. The "direction" of their argument is from human nature to the nature of law, rather than from observations about law to the nature of law. Fully cognizant of the fact that there are considerable differences between legal systems, this sort of approach is unlikely to try to distil the few features that make something into a legal system, but rather try and identify what facts about human nature entail (if anything at all) about the shape legal institutions are likely to take. Though the aspiration is to identify some such universal tendencies among humans, it does not require the discovery of necessary truths.

What such inquiries might reveal about law is not a topic I can address in a few pages. The only purpose of the discussion has been to show where I think legal philosophers should be looking if they seek more universalist findings about law in general. But ending on this note may seem to undermine the thrust of everything I have said before. That, however, is not a challenge to me, but to reality. It reflects one of the most difficult questions in the explanation of all of human affairs, namely how to reconcile the fact of universal human nature with the fact of immensely different cultures. Swings in popular and academic opinion on the matter-the sixties and seventies were the "relativistic" decades, and now universalism is on the up ${ }^{30}$-reflect the extent to which this complex question may be influenced by shifting fashions, but it seems clear that there is quite a bit of both in all human societies, and that a complete account of social institutions would have to take account of both.

Legal philosophers may have thought that they could contribute to the universal end of the inquiry by taking on questions that seemed to be independent of scientific inquiry and even human nature: the "nature" of law is not a question that seems amenable to scientific inquiry (Priel 2012a), but the difficulties with this sort of inquiry, some of which have been shown here, make this alternative unattractive. The universalist alternative proposed here avoids these difficulties, but poses a different challenge to legal philosophers. Put bluntly, it seems to leave little room for philosophical contribution now that the research on human nature has largely been taken up by scientists. This means legal philosophers will have to rethink what they are doing. One possibility is for them to serve as a kind of

${ }^{30}$ Consider the following titles: The Language Instinct: How the Mind Creates Language (Pinker 1994): "The Moral Instinct" (Pinker 2008); The Art Instinct: Beauty, Pleasure, and Human Evolution (Dutton 2010); The Faith Instinct: How Religion Evolved Why It Endures (Wade 2009); "The Property 'Instinct'" (Stake 2004); "Is There a Law Instinct?" (Guttentag 2009); The Compassionate Instinct: The Science of Human Goodness (Keltner et al. 2010). 
go-between trying to connect the general, scientific inquiry on human nature with the diverse, normative examination of diverse social institutions. Beyond that, legal theorists will have to turn to political theory and explain the place of law within it. Thus, in the end, we reach a conclusion similar to the one I have made in the beginning of this section: jurisprudents are most like to make a real contribution by adopting a more consciously normative approach to legal theory, one that relies on scientific findings on human nature for the sake of a better theory of the proper role of law. To do that, however, legal philosophers must be willing to open up their discipline both to political theory and to scientific work on human nature.

\section{Conclusion}

This has been a story with a twist. Much of the work in jurisprudence of the last fifty years has been concerned with the discovery of objective truth about the "nature" of law. What I have argued here is that to find the answer to this question one needs to understand the way the idea of objectivity in law is understood, and how different political traditions have led to different characterizations of law in response to the problem of objectivity. If one accepts that there is no one way of understanding the relationship between law and politics and that the way this relationship is understood touches upon and affects the most basic aspects of what law is, then it follows that there is also no single answer to the question of the nature of law.

Why has this conclusion eluded some very sophisticated thinkers? One reason must be that the debate about the nature of law has been framed as a debate about the relationships between law and morality. But the focus on the relationships, necessary or otherwise, between law and morality has obscured from view questions about the relationships between law and politics, questions which arguably are far more important for understanding law in the modern regulatory state. Understanding the law-politics relationship calls for more attention to law's daily workingsthe way judges understand their position in relation to other branches of government, the way judges are appointed, the way they write their opinions, the way law is taught, as well as the way political elites perceive the right way of solving social problems. It requires a broader view of what law does: It is no coincidence, I think, that when legal philosophers write about substantive law they focus on common law areas, those that fit the law-morality divide far better than areas such as securities regulation or administrative law (which highlight the law-politics divide). One of the unfortunate implications of the focus on the "nature" of law within jurisprudence is that those working in jurisprudence have come to see all this as irrelevant detail, not sufficiently interesting or important for serious philosophical reflection. The result has been a growing gulf, almost a conceptual separation, between law and jurisprudence. If nothing else, I hope this chapter has shown that this has not helped make jurisprudential debates more philosophically sophisticated or better focused, and it has not helped to get us closer to finding the general features of law. 


\section{References}

Abel, R. L. (1987). "The Real Tort Crisis: Too Few Claims,", Obio State Law Journal, 48: 443-67.

Ascherson, N. (2004). "Law v, Order," London Review of Books, 20 May, 22-4.

Atiyah, P. S. and Summers, R. S. (1987). Form and Substance in Anglo-American Law: A Comparative Study of Legal Reasoning, Legal Theory, and Legal Institutions. Oxford: Clarendon Press.

Bagehot, W. (1963). The English Constitution. Edited by Richard Crossman. Second edition. London: Fontana (second edition first published in 1872).

Bailyn, B. (1992). The Ideological Origins of the American Revolution. Enlarged edition. Cambridge, MA: Harvard University Press.

Barber, S. A. and Fleming, J. E. (2007). Constitutional Interpretation: The Basic Questions. New York: Oxford University Press.

Barry, B. (1979). "And Who Is My Neighbor?," Yale Law Journal, 88: 629-58.

Birks, P. (1996). "Equity in Modern Law: An Exercise in Taxonomy," University of Western Australia Law Review, 26: 1-99.

Bogus, C. T. (2001). Why Lawsuits Are Good for America: Disciplined Democracy, Big Business and the Common Law. New York: New York University Press.

Bryce, J. (1901). Studies in the History of Jurisprudence, vol. 2. Oxford: Clarendon Press. Cohen, M. R. (1916). "The Place of Logic in the Law," Harvard Law Review, 29: 622-39. Crick, B. (2000). In Defence of Politics. Fifth edition. London: Continuum.

Darwall, S., et al. (1992). "Toward a fin-de-siècle Ethics: Some Trends," Philosophical Review, 101: 115-89.

Dewey, J. (1924). "Logical Method and Law," Philosophical Review, 33: 560-72.

Dickson, J. (2009). "Is Bad Law Still Law? Is Bad Law Really Law?," in M. Del Mar and Z. Bankowski (eds.), Law as an Institutional Normative Order. Burlington, VT: Ashgate, $161-83$.

Drewry, G. (1985). "The GCHQ Case: A Failure of Government Communications," Parliamentary Affairs, 38: 371-86.

Drewry, G. (2009). "A Political Scientist's Perspective," in Louis Blom-Cooper et al. (eds.), The Judicial House of Lords 1876-2009. Oxford: Oxford University Press, 439-53.

Dutton, D. (2010). The Art Instinct: Beauty, Pleasure, and Human Evolution. Paperback edition. New York: Bloomsbury.

Dworkin, R. (1978). Taking Rights Seriously. Revised edition. Cambridge, MA: Harvard University Press.

Dworkin, R. (1985). A Matter of Principle. Cambridge, MA: Harvard University Press.

Dworkin, R. (1986). Law's Empire. Cambridge, MA: Harvard University Press.

Dworkin, R. (1990). A Bill of Rights for Britain. London: Chatto and Windus.

Dworkin, R. (1996). Freedom's Law: The Moral Reading of the American Constitution. Cambridge, MA: Harvard University Press.

Dworkin, R. (2000). Sovereign Virtue: The Theory and Practice of Equality. Cambridge, MA: Harvard University Press.

Dworkin, R. (2006). Is Democracy Possible Here? Principles for a New Political Debate. Princeton: Princeton University Press.

Dworkin, R. (2011). Justice for Hedgehogs. Cambridge, MA: Harvard University Press. 
Endicott, T. A. O. (1998). Book review, Law Quarterly Review 114: 511-15.

Fiss, O. (2001). The Law as It Could Be. New York: New York University Press.

Fodor, J. (2004). "Water's Water Everywhere," London Review of Books, 21 October: 17-19.

Friedman, B. (2004). "The Importance of Being Positive: The Nature and Function of Judicial Review," University of Cincinnati Law Review, 72: 1257-303.

Gardner, J. (2004). "The Legality of Law," Ratio Juris, 17: 168-81.

Goldsworthy, J. (2001). The Sovereignty of Parliament: History and Philosophy. Oxford: Oxford University Press.

Gough J. W. (1961). Fundamental Law in English Constitutional History. New edition. Oxford: Clarendon Press.

Graber, M. (2004). "Resolving Political Questions into Judicial Questions: Tocqueville's Thesis Revisited," Constitutional Commentary, 21: 485-545.

Griffith, J. A. G. (1979). "The Political Constitution," Modern Law Review, 42: 1-21.

Guttentag, M. D. (2009). "Is There a Law Instinct?," Washington University Law Review, 87: 269-328.

Harman, G. (1999). "Doubts about Conceptual Analysis," in Reasoning, Meaning, and Mind. New York: Oxford University Press, 138-43.

Hart, H. L. A. (1983). Essays in Jurisprudence and Philosophy. Oxford: Clarendon Press.

Hart, H. L. A. (1958). "A View of America," The Listener, 59: 89-90.

Hart, H. L. A. (1976). "Bentham and the USA," Journal of Law and Economics, 19: 547-67.

Hart, H. L. A. (1994). The Concept of Law. Second edition. Oxford: Clarendon Press.

Holmes, O. W. (1881). The Common Law. Boston: Little, Brown.

Holmes, O. W. (1897). "The Path of the Law," Harvard Law Review, 10: 457-78.

Jackson, F. and Pettit, P. (2004). "In Defence of Explanatory Ecumenism," in Mind, Morality, and Explanation: Selected Collaborations. Oxford: Clarendon Press, 163-85.

Kahn, J. (2006). "The Search for Rule of Law in Russia," Georgetown Journal of International Law, 37: 353-409.

Kar, R. B. (2006). "The Deep Structure of Law and Morality," Texas Law Review, 84: 877-942.

Keltner, D., et al. (eds.) (2010). The Compassionate Instinct: The Science of Human Goodness. New York: W. W. Norton.

Kitcher, P. (1992). "The Naturalists Return," Philosophical Review, 101: 53-114.

Kurkchiyan, M. (2003). "The Illegitimacy of Law in Post-Soviet Societies," in D. J. Galligan and Marina Kurkchiyan (eds.), Law and Informal Practices: The Post-Communist Experience. Oxford: Oxford University Press, 25-46.

Lacey, N. (2006). A Life of H. L. A. Hart: The Nightmare and the Noble Dream. Oxford: Oxford University Press.

Legrand, P. (1997). "Against a European Civil Code," Modern Law Review, 60: 44-63.

Markesinis, B. S. (1986). "Conceptualism, Pragmatism and Courage: A Common Lawyer Looks at Some Judgments of the German Federal Court," American Journal of Comparative Law, 34: 349-67.

Marmor, M. (2001). Positive Law and Objective Values. Oxford: Oxford University Press.

Mikhail, J. (2011). Elements of Moral Cognition: Rawls' Linguistic Analogy and the Cognitive Science of Moral and Legal Judgment. New York: Cambridge University Press, 2011. 
Moore, M. S. (2000). Educating Oneself in Public: Critical Essays in Jurisprudence. Oxford: Oxford University Press.

Oakeshott, M. (1975). "The Vocabulary of a Modern European State (Concluded)," Political Studies, 23: 409-14.

Peretti, T. J. (1999). In Defense of a Political Court. Princeton: Princeton University Press.

Pinker, S. (1994). The Language Instinct: How the Mind Creates Language. New York: HarperCollins.

Pinker, S. (2002). The Blank Slate: The Modern Denial of Human Nature. London: Penguin.

Pinker, S. (2008). "The Moral Instinct," The New York Times (Magazine), 13 January.

Priel, D. (2007a). "In Search of Argument," Texas Law Review, 86: 141-64.

Priel, D. (2007b). "Jurisprudence and Necessity," Canadian Journal of Law and Jurisprudence, 20: 173-200.

Priel, D. (2008). "The Boundaries of Law and the Purpose of Legal Philosophy," Law and Philosophy, 27: 643-95.

Priel, D. (2011a). "The Place of Legitimacy in Legal Theory," McGill Law Journal, 57: $1-35$.

Priel, D. (2011b). "Jurisprudence and Psychology," in Maksymilian Del Mar (ed.), New Waves in Philosophy of Law. London: Palgrave Macmillan, 77-99.

Priel, D. (2012a). "Jurisprudence between Science and the Humanities," Washington University Jurisprudence Review, 4: 269-324.

Priel, D. (2012b). "Are Jurisprudential Debates Conceptual? Some Lessons from Democratic Theory," Osgoode Hall Law Journal, 50.

Priel, D. (unpublished). "Towards Classical Legal Positivism," available at <http://ssrn.com/ abstract $=1886517>$.

Raz, J. (2009). Between Authority and Interpretation: On the Theory of Law and Practical Reason. Oxford: Oxford University Press.

Schauer, F. (2005). "The Supreme Court 2005 Term Foreword: The Court's Agenda—and the Nation's," Harvard Law Review, 120: 4-64.

Shapiro, S. J. (2011). Legality. Cambridge, MA: Harvard University Press.

Sidgwick, H. (1897). The Elements of Politics. Second edition. London: Macmillan.

Stake, J. E. (2004). "The Property 'Instinct'," Philosophical Transactions of the Royal Society London B, 359: 1763-74.

Stevens, R. (1978). Law and Politics: The House of Lords as a Judicial Body, 1800-1976. Chapel Hill: University of North Carolina Press.

Stevens, R. (2005). The English Judges: Their Role in the Changing Constitution. Revised edition. Oxford: Hart Publishing.

Stevens, R. (2009). "Torts," in Louis Blom-Cooper et al. (eds.), The Judicial House of Lords 1876-2009. Oxford: Oxford University Press, 629-52.

Stich, S. P. (1990). The Fragmentation of Reason: Preface to a Pragmatic Theory of Cognitive Evaluation. Cambridge, MA: MIT Press.

Tiedeman, C. G. (1890). The Unwritten Constitution of the United States: A Philosophical Inquiry into the Fundamentals of American Constitutional Law. New York: G. P. Putnam's Sons.

Timmons, M. (1999). Morality without Foundations: A Defense of Ethical Contextualism. New York: Oxford University Press. 
Tocqueville, A. de (2003). Democracy in America and Two Essays on America. Translated by Gerald E. Bevan, edited by Isaac Kramnick. London: Penguin (first published 1835).

Van Fraassen, B. C. (2002). The Empirical Stance. New Haven: Yale University Press.

Waddams, S. (2003). Dimensions of Private Law: Categories and Concepts in Anglo-American Legal Reasoning. Cambridge: Cambridge University Press.

Wade, N. (2009). The Faith Instinct: How Religion Evolved and Why It Endures. New York: Penguin Press.

Wechsler, H. (1958). "Toward Neutral Principles of Constitutional Law," Harvard Law Review, 73: 1-35.

Wood, G. S. (2002). The American Revolution: A History. New York: Modern Library.

Zimmermann, R. (2005). "Characteristic Aspects of German Legal Culture," in M. Reimann and J. Sekoll (eds.), Introduction to German Law. The Hague: Kluwer Law International, $1-51$. 